Thorax (1974), 29, 482.

\title{
Primary leiomyosarcoma of the lung
}

\author{
T. RAMANA T H A N ${ }^{1}$ \\ London Chest Hospital, Bonner Road, London
}

\begin{abstract}
Ramanathan, T. (1974). Thorax, 482-489. Primary leiomyosarcoma of the lung. Three new cases of primary leiomyosarcoma of the lung are presented. The relevant literature has been reviewed. The similarity in the clinical features between bronchogenic carcinoma and leiomyosarcoma is emphasized. The only distinctive feature of leiomyosarcoma is the absence of lymph node involvement.
\end{abstract}

A review of the literature shows that primary leiomyosarcoma of the lung is a rare tumour. Agnos and Starkey (1958) were able to find 18 recorded cases and added two of their own. In the most recent review, Dyson and Trentalance (1964) reported 26 cases. The purpose of this paper is to report three new cases and to discuss problems associated with this condition in the light of previous reports.

\section{REVIEW OF THE LITERATURE}

Forty-seven cases of leiomyosarcoma have now been reported and detailed information is available on 32 of these (Table I). The earliest case was reported in 1907 by Davidsohn (cited by Forkel, 1909). The majority of cases have been reported in the last two decades.

The ages of these 32 patients range from 4 to 79 years. Twenty of the 32 were over the age of 40 years. There were 22 males and 10 females. The left lung was involved in 16 cases and the right lung in 15 , and one case had tumour in both lungs.

All patients had chest symtoms and the commonest, in order of frequency, were cough (22 cases); dyspnoea (18 cases); chest pain (13 cases); sputum (11 cases); haemoptysis (11 cases); and weight loss (9 cases).

Finger clubbing was rare and was reported in only one case (Brunn and Goldman, 1940) and cyanosis was present in five cases. The commonest sign was diminished air entry to the side of the lesion. Consolidation of part of the lung (three cases) and basal crepitations (one case) were also noted.

In 28 of the 32 cases radiological examination

'Present address: Department of Surgery, University of Malaya, Kuala Lumpur, Malaysia was carried out. A mass in either the trachea, bronchi or lungs was found in 21 cases. In three cases there was atelectasis, in two there was consolidation of a lobe, and in another two there was diffuse haziness of the base.

Bronchoscopy was performed in 20 of the 32 patients. In 12 cases tumour was seen in the bronchial tree, in two cases blood only was present, and in the remaining six cases the bronchial tree was passed as normal.

Examination of the sputum for neoplastic cells was unsuccessful in all except one case where atypical cells were noted (Watson and Anlyan, 1954).

In five of the 32 cases the diagnosis was made at necropsy. Two patients refused surgical intervention but the diagnosis was made by bronchoscopy. The remaining 25 underwent surgery. Two of the 25 died on the operating table; eight underwent pneumonectomies, six had a lobectomy, two had excision of a polyp, and two had enucleation of a tumour. In two cases the nature of the operation was not stated and in one case the tumour was not resectable and was treated by irradiation.

Macroscopically the tumour varied from $1 \mathrm{~cm}$ to $16 \mathrm{~cm}$ in diameter. The cut surface was seen to be grey or white and was usually firm but in some cases soft areas were also present. In two cases the tumour was polypoid with no extrabronchial extension. In nine cases tumour was present in the larger bronchi with extension into the lung parenchyma. In seven cases distant metastases were present, including the liver, pleura, adrenals, and brain. Hilar lymph node metastases were not described in any of the cases.

Excluding the two operative deaths, one patient was alive 21 years after operation (Ochsner and Ochsner, 1958) while another survived only two 
T A B L E I

PREVIOUSLY RECORDED CASES OF LEIOMYOSARCOMA OF LUNG

\begin{tabular}{|c|c|c|c|c|c|c|c|}
\hline Reference & Age/Sex & Radiograph & Bronchoscopy & Treatment & Macroscopy & Metastases & Survival \\
\hline Neumann (1938) & $66 \mathrm{~F}$ & - & - & & $\begin{array}{l}\text { Tumour of } \\
\text { LUL }\end{array}$ & Not known & $\begin{array}{l}\text { Died before } \\
\text { operation }\end{array}$ \\
\hline $\begin{array}{l}\text { Brunn and Goldman } \\
(1940)\end{array}$ & $55 \mathrm{M}$ & $\begin{array}{l}\text { Shadow } \mathbf{L} \\
\text { lower lung field }\end{array}$ & $\begin{array}{l}\text { Polypoid mass } \\
\text { in orifice LLL }\end{array}$ & $\begin{array}{l}\text { Refused } \\
\text { surgery }\end{array}$ & - & Not known & $2 \mathrm{mth}$ \\
\hline $\begin{array}{l}\text { Randall and Blades } \\
\text { (1946) }\end{array}$ & $34 \mathrm{M}$ & $\begin{array}{l}\mathbf{R} \text { hilar } \\
\text { shadow }\end{array}$ & $\begin{array}{l}\text { Smooth, } \\
\text { rounded mass } \\
\text { occluding } \mathbf{R} \\
\text { main bronchus } \\
\text { at level of } \\
\text { carina }\end{array}$ & 一 & $\begin{array}{l}2 \mathrm{~cm} \text { diam. } \\
\text { mass attached } \\
\text { to carina. } \\
\text { Another mass } \\
\text { filling } R \text { main } \\
\text { bronchus }\end{array}$ & $\begin{array}{l}\text { Lymph nodes } \\
\text { not involved }\end{array}$ & $\begin{array}{l}\text { Died at } \\
\text { operation }\end{array}$ \\
\hline Johnson et al. (1952) & $52 \mathrm{M}$ & $\begin{array}{l}\text { Opacity in } \\
\text { RUL? } \\
\text { collapse }\end{array}$ & $\begin{array}{l}\text { RUL orifice } \\
\text { not seen }\end{array}$ & $\begin{array}{l}\text { Pneumonec- } \\
\text { tomy }\end{array}$ & $\begin{array}{l}0.5 \times 1.2 \mathrm{~cm} \\
\text { mass occluding } \\
\text { RUL bronchus }\end{array}$ & $\begin{array}{l}\text { Lymph nodes } \\
\text { not involved }\end{array}$ & 3 yr Well \\
\hline $\begin{array}{l}\text { Killingsworth et al. } \\
\text { (1953) }\end{array}$ & $7 \mathrm{~F}$ & Mass in $L$ side & $\begin{array}{l}\text { Mass in } \mathbf{L} \\
\text { main bronchus }\end{array}$ & $\begin{array}{l}\text { L pneumo- } \\
\text { nectomy }\end{array}$ & $\begin{array}{l}\text { Tumour in } L \\
\text { lower lobe }\end{array}$ & $\begin{array}{l}\text { No lymph } \\
\text { nodes at opn. } \\
\text { Extension of } \\
\text { tumour into } \\
\text { atrium via } \\
\text { pulmonary vein }\end{array}$ & $\begin{array}{l}\text { Well } 2 \text { yr } \\
\text { postop. }\end{array}$ \\
\hline \multirow[t]{6}{*}{$\begin{array}{l}\text { Watson and Anlyan } \\
\text { (1954) }\end{array}$} & $57 \mathbf{M}$ & $\begin{array}{l}\text { Soft tissue } \\
\text { shadow } 3 \cdot 5 \times \\
5 \cdot 5 \mathrm{~cm} \text { in } \mathbf{R} \\
\text { lower lung } \\
\text { field }\end{array}$ & $\begin{array}{l}\text { Growth in } \\
\text { RLL. } \\
\text { Cytology - ve } \\
\text { Biopsy - ve }\end{array}$ & $\begin{array}{l}\mathbf{R} \text { middle and } \\
\text { lower } \\
\text { lobectomy }\end{array}$ & $\begin{array}{l}\text { Tumour in } \\
\text { medial segment } \\
\text { of middle lobe } \\
7 \mathrm{~cm} \text { diam. }\end{array}$ & Nil at opn. & $\begin{array}{l}\text { Well } 6 \text { yr } \\
\text { postop. }\end{array}$ \\
\hline & $63 \mathrm{~F}$ & $\begin{array}{l}\text { Mass in } \mathbf{L} \\
\text { upper lung } \\
\text { field }\end{array}$ & $\begin{array}{l}\text { Not done. } \\
\text { Sputum } \\
\text { cytology - ve }\end{array}$ & $?$ & $\begin{array}{l}\text { LUL tumour } \\
9 \times 7 \times 4 \mathrm{~cm}\end{array}$ & Nil at opn. & 5 yr Well \\
\hline & $66 \mathrm{~F}$ & $\begin{array}{l}\text { Mass adjacent } \\
\text { to } L \text { cardiac } \\
\text { border } 7.5 \mathrm{~cm} \\
\text { diam. }\end{array}$ & $\begin{array}{l}\text { Normal. } \\
\text { Cytology - ve } \\
\text { atypical cells }\end{array}$ & $\begin{array}{l}\text { Non- } \\
\text { resectable. } \\
\text { Radiotherapy }\end{array}$ & $\begin{array}{l}\text { Bulky, soft } \\
\text { cystic tumour } \\
\text { in upper and } \\
\text { anterior part } \\
\text { of LLL }\end{array}$ & $\begin{array}{l}\text { Metastases to } \\
\text { visceral } \\
\text { pleura at opn. }\end{array}$ & $\begin{array}{l}\text { Died } 1 \text { yr } \\
\text { postop. } \\
\text { ? cause }\end{array}$ \\
\hline & $66 \mathrm{M}$ & $\begin{array}{l}\text { Routine CXR. } \\
\text { Mass in RLL } \\
4 \mathrm{~cm} \text { diam. }\end{array}$ & $\begin{array}{l}\text { Normal. } \\
\text { Cytology - ve }\end{array}$ & $\begin{array}{l}\text { Enucleation } \\
\text { and removal } \\
\text { of part of lung }\end{array}$ & $\begin{array}{l}\text { Tumour in } \\
\text { RML } \\
10 \times 6 \times 4 \mathrm{~cm}\end{array}$ & Nil at opn. & $\begin{array}{l}\text { Well } 3 \text { yr } \\
\text { postop. }\end{array}$ \\
\hline & $4 M$ & $\begin{array}{l}\text { Tumour in } \mathbf{R} \\
\text { main bronchus. } \\
\text { Hyperinflation } \\
\text { of left lobe }\end{array}$ & $\begin{array}{l}\text { Tumour in } \\
\text { RML bronchus }\end{array}$ & Thoracotomy & $\begin{array}{l}\text { Tumour in } R \\
\text { hilum involving } \\
\mathbf{R M} \text { bronchus. } \\
\text { Complete } \\
\text { collapse of } \\
\mathbf{R} \text { lung. } \\
5 \times 19 \mathrm{~cm}\end{array}$ & $\begin{array}{l}\text { Nil at } \\
\text { necropsy }\end{array}$ & $\begin{array}{l}\text { Died at opn. } \\
\text { due to cardiac } \\
\text { arrest. }\end{array}$ \\
\hline & $67 M$ & $\begin{array}{l}\text { Mass in } \\
\text { inferior } L \\
\text { hemithorax } \\
4 \mathrm{~cm} \text { diam. }\end{array}$ & $\begin{array}{l}\text { Bleeding from } \\
\text { LLL bronchus }\end{array}$ & $\begin{array}{l}\text { Refused } \\
\text { surgery }\end{array}$ & - & $\begin{array}{l}\text { Not known. } \\
\text { No surgery or } \\
\text { biopsy }\end{array}$ & $\begin{array}{l}\text { Died } 2 \text { yr after } \\
\text { diagnosis } \\
\text { ? cause }\end{array}$ \\
\hline $\begin{array}{l}\text { Rosenberg et al. } \\
\text { (1955) }\end{array}$ & $62 M$ & $\begin{array}{l}\text { Mass in R } \\
\text { hilum } \\
\text { extending into } \\
\text { lung }\end{array}$ & $\begin{array}{l}\text { Middle lobe } \\
\text { bronchus } \\
\text { tumour } 2 \mathrm{~cm} \\
\text { distal to carina }\end{array}$ & $\begin{array}{l}\text { R pneu- } \\
\text { monectomy }\end{array}$ & $\begin{array}{l}1 \text { cm mass in } \mathbf{R} \\
\text { middle lobe } \\
\text { extending into } \\
\mathbf{R} \text { main } \\
\text { bronchus }\end{array}$ & Nil & 13 mth Alive \\
\hline Tocker et al. (1957) & $19 \mathrm{M}$ & $\begin{array}{l}\text { Large rounded } \\
\text { tumour mass } \\
\text { behind heart } \\
\text { shadow }\end{array}$ & Negative & $\begin{array}{l}\text { L pneu- } \\
\text { monectomy }\end{array}$ & $\begin{array}{l}\text { Large rounded } \\
\text { tumour in post } \\
\text { and medial } \\
\text { portion of } \\
\text { LLL } 11 \mathrm{~cm} \\
\text { diam. }\end{array}$ & $\begin{array}{l}\text { Lymph nodes } \\
\text { not involved } \\
\text { at operation. } \\
\text { At necropsy } \\
\text { nodes involved, } \\
\text { skin } R \text { lung } \\
\text { and } R \text { thigh }\end{array}$ & $\begin{array}{l}9 \text { months Died } \\
\text { from recurrent } \\
\text { disease }\end{array}$ \\
\hline Hicks (1957) & $79 \mathrm{M}$ & $\begin{array}{l}\text { Patchy } \\
\text { infiltration } \\
\text { both lung } \\
\text { fields. Dense } \\
\text { shadow in R } \\
\text { hilum }\end{array}$ & 一 & $\begin{array}{l}\text { Died before } \\
\text { operation }\end{array}$ & $\begin{array}{l}\text { RUL orifice } \\
\text { tumour } 10 \mathrm{~cm} \\
\text { diam. Tumour } \\
\text { nodules in both } \\
\text { lungs }\end{array}$ & $\begin{array}{l}\text { Hilar nodes } \\
\text { and liver }\end{array}$ & $\begin{array}{l}16 \text { days Died } \\
\text { from cardiac } \\
\text { failure }\end{array}$ \\
\hline $\begin{array}{l}\text { Hewlett and McCarty } \\
\text { (1958) }\end{array}$ & $23 \mathrm{M}$ & Mass in RLL & - & $\begin{array}{l}\mathbf{R} \text { lower } \\
\text { lobectomy }\end{array}$ & $\begin{array}{l}4 \mathrm{~cm} \text { mass in } \\
\text { basal segments } \\
\text { of } R \text { lower } \\
\text { lobes }\end{array}$ & Nil & $\begin{array}{l}\text { Well } 1 \text { yr } \\
\text { postop. }\end{array}$ \\
\hline
\end{tabular}


T A B L E I (continued)

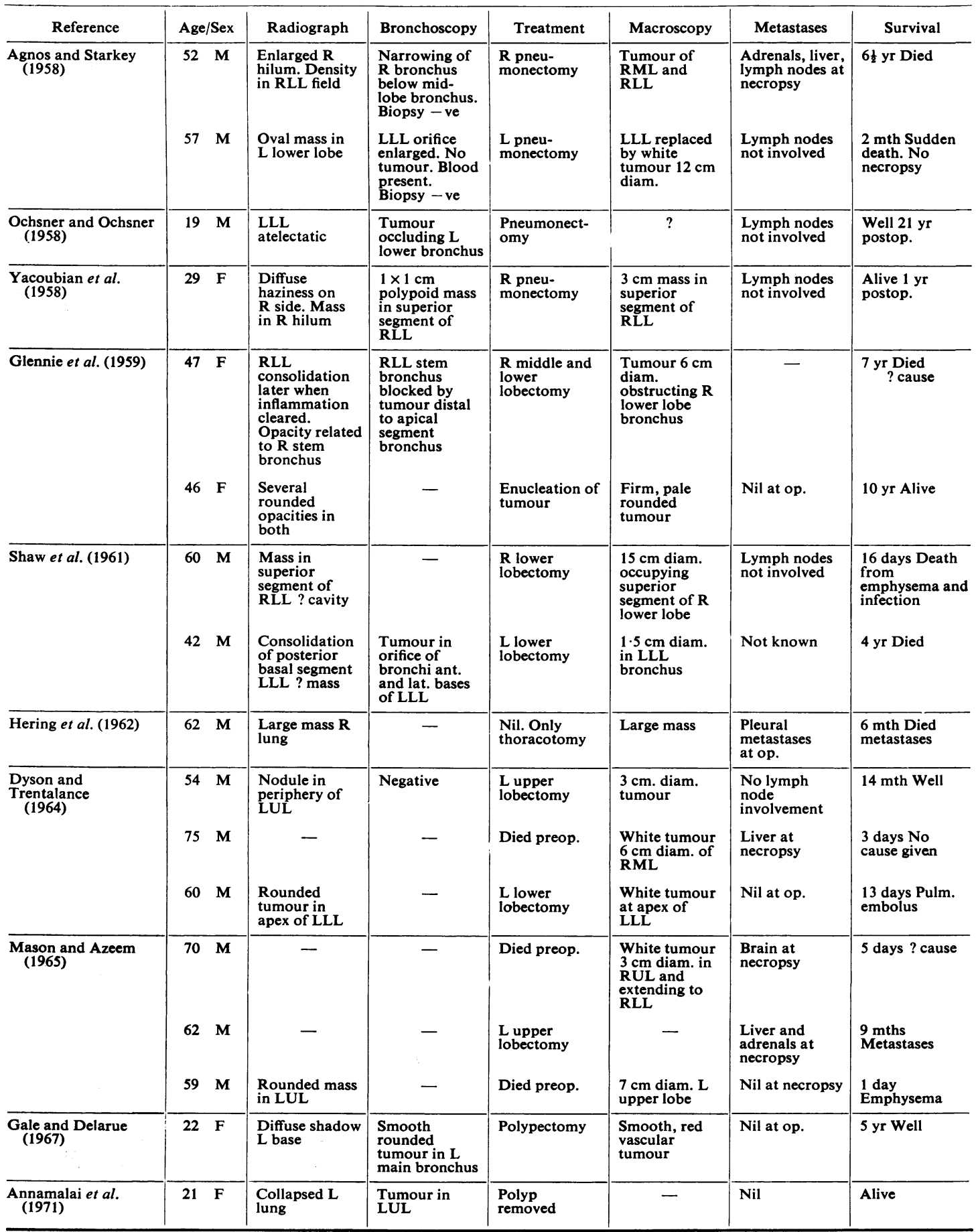


months. Of the 32 patients, 16 survived at least one year and eight for more than three years after diagnosis. The case which was non-resectable survived for six months. Of the two patients who refused surgery, one lived for two months and the other for one year. Of the eight who had a pneumonectomy, three lived for three years or more and the rest for less than two years. Of the six patients who had one or more lobes removed, three lived for more than three years and the others for one year or less. One patient who had a polypoid tumour removed survived for five years while another is still alive after one year.

\section{CASE REPORTS (TABLE II)}

CASE 1 In January 1969 this 53-year-old patient, who smoked 10 cigarettes each day, suddenly developed a febrile illness and fatigue. A chest radiograph (Fig. 1)

T A B L E I I

PRESENT SERIES

\begin{tabular}{|c|c|c|c|c|c|c|c|}
\hline \multicolumn{2}{|c|}{ Age/Sex } & \multirow{2}{*}{$\frac{\text { Radiograph }}{\text { Shadow in L lung }}$} & \multirow{2}{*}{$\begin{array}{l}\text { Bronchoscopy } \\
\text { White tumour } \\
\text { projecting from } \\
\text { LUL orifice and } \\
\text { blocking LLL } \\
\text { bronchus }\end{array}$} & \multirow{2}{*}{$\frac{\text { Treatment }}{\text { L pneumonectomy }}$} & \multirow{2}{*}{\begin{tabular}{l}
\multicolumn{1}{c}{ Macroscopy } \\
7 cm diam. \\
tumour in LUL \\
extending to aorta \\
and chest wall
\end{tabular}} & \multirow{2}{*}{$\begin{array}{c}\text { Metastases } \\
\text { Hilar gland not } \\
\text { involved at opn. }\end{array}$} & \multirow{2}{*}{$\frac{\text { Survival }}{1 \mathrm{yr} \text {; dead }}$} \\
\hline & $\mathbf{F}$ & & & & & & \\
\hline 57 & $\mathbf{M}$ & $\begin{array}{l}\text { Mass in post. } \\
\text { segment of RUL }\end{array}$ & Normal & $\begin{array}{l}\mathbf{R} \text { upper and } \\
\text { middle lobectomy }\end{array}$ & $\begin{array}{l}\text { Tumour mass in } \\
\mathbf{R} \text { upper and } \\
\text { middle lobes }\end{array}$ & $\begin{array}{l}\text { Hilar glands not } \\
\text { involved }\end{array}$ & $\begin{array}{l}\text { Alive } 6 \mathrm{mth} \\
\text { postop. }\end{array}$ \\
\hline & $\mathbf{F}$ & $\begin{array}{l}\text { Large mass in } \\
\text { apex of } R \text { lung. } \\
\text { Smaller mass in } \\
\text { periphery of RLL }\end{array}$ & Normal & $\begin{array}{l}\text { Thoracotomy; } \\
\text { non-resectable }\end{array}$ & $\begin{array}{l}\text { Large mass } \\
\text { occupying entire } \\
\text { upper lobe and } \\
\text { fixed to chest wall }\end{array}$ & $\begin{array}{l}\text { Metastases to } \\
\text { diaphragm, pleura } \\
\text { and lateral chest } \\
\text { wall }\end{array}$ & Died $1 \mathrm{mth}$ postop. \\
\hline
\end{tabular}

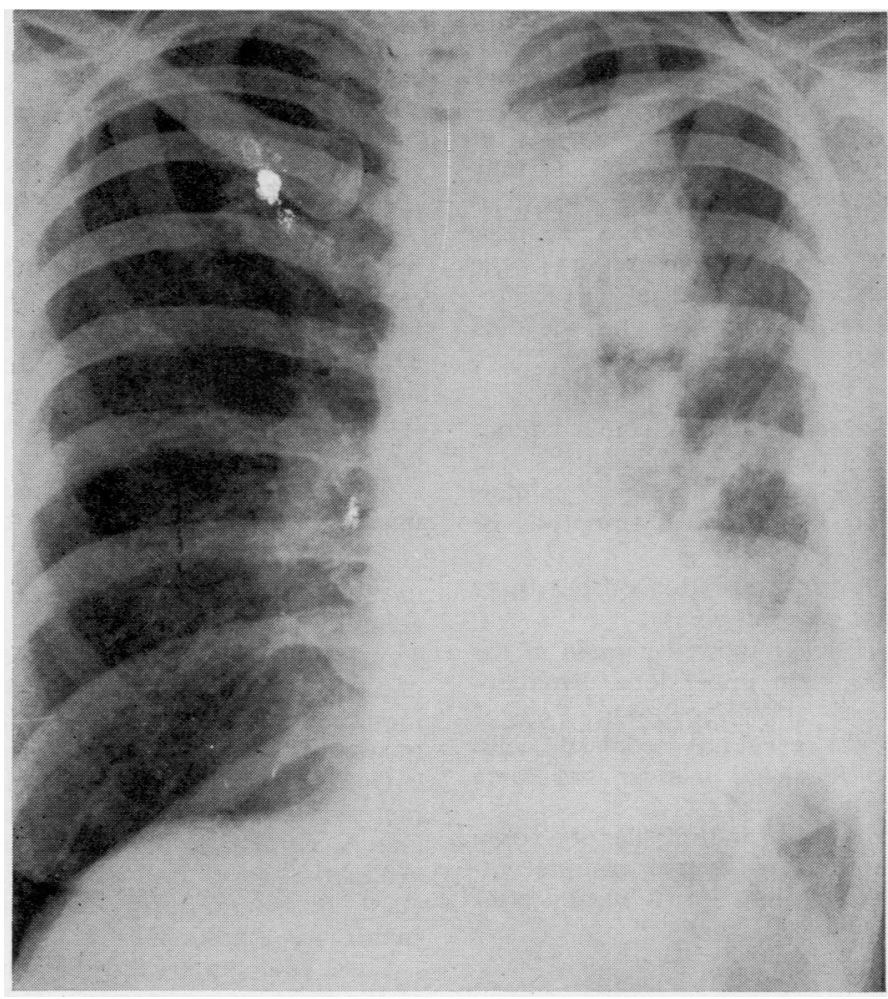

FIG. 1. Case 1. PA chest radiograph. 
showed a shadow in the left lung field. She was treated with antibiotics under the assumption that the lesion was inflammatory. In May 1969 bronchoscopy showed a normal bronchial tree. She was kept under observation and in October 1969 she developed cough and sputum. In January 1970 a repeat bronchoscopy revealed a white tumour projecting from the left upper lobe orifice, blocking the left lower lobe orifice, and biopsy showed this to consist of medium-sized rounded and spindle-shaped cells with irregular nuclei. The appearance suggested sarcoma of the lung.

On examination her general condition was satisfactory. She had early clubbing of the fingers but no lymphadenopathy nor other abnormal physical signs. Chest radiographs revealed a spherical shadow in the left upper zone. There was also patchy and irregular shadowing in the left lower lobe.

Sputum cytology did not reveal any neoplastic cells.

In January 1971 left pneumonectomy was performed and a tumour, $7 \mathrm{~cm}$ in diameter, was found in the left upper lobe, extending to the aorta and chest wall.

Histology There is a large mass of growth $(8.5 \times 7 \times 5 \mathrm{~cm}$ diam. $)$ in the upper lobe. The cut surface shows a main mass of growth with several adjacent nodules. Growth is present in and occludes the upper lobe bronchus. It has a generally firm greyish-white appearance with some central necrosis. In one or two places the tissue has a streaky yellow appearance.

Microscopically (Fig. 2) the growth consists of elongated cells with hyperchromatic nuclei. Mitotic figures are present. In the bronchus the growth is covered by bronchial epithelium. Areas of necrosis are seen in a few places. It is a leiomyosarcoma of the lung. Hilar lymph nodes are not involved by tumour.

The patient's condition deteriorated and she died one year after operation.

CASE 2 This 57-year-old man, who had smoked about 20 cigarettes each day for the preceding 30 years, was well until December 1971 when he developed painless haematuria. He had no history of haemoptysis or weight loss.

On examination his fingers were clubbed but there were no other abnormal physical signs.

A chest radiograph (Fig. 3) showed a mass in the posterior segment of the right upper lobe. Bronchoscopy was normal.

Sputum cytology did not reveal any neoplastic cells. On cystoscopy a transitional-cell bladder papilloma was discovered and removed.

In January 1972 a right upper and middle lobectomy was performed. His postoperative course was uneventful and he was discharged home two weeks after operation.

Histology (FIG. 4) The tumour is composed of large spindle-shaped cells with a variable amount of cyto-

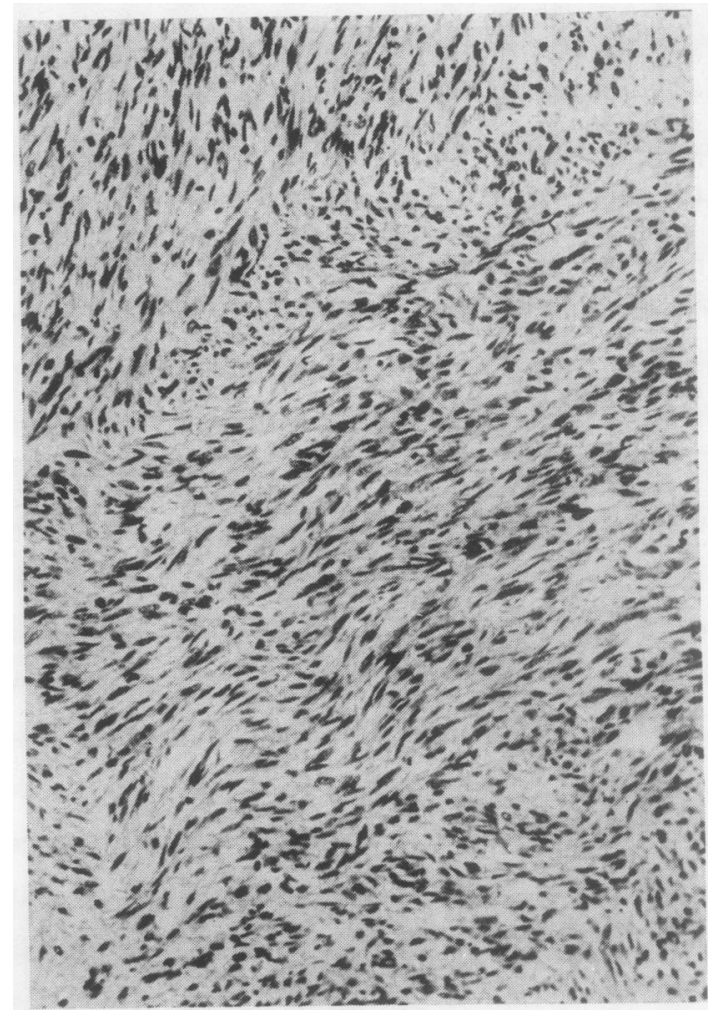

FIG. 2. Case 1. Elongated cells with hyperchromatic nuclei; mitotic figures are present $(\times 130)$.

plasm and large vesicular nuclei. Some nuclei are extremely large, and nucleoli are prominent. Collagen fibres are seen running between the individual cells. There are no cytoplasmic cross-striations. Foci of necrosis are seen. There is no tumour in the hilar lymph nodes. The tumour is a leiomyosarcoma of the lung.

The section of the lymph node from below the left upper lobe bronchus appears normal.

CASE 3 A 65-year-old woman, who had smoked 20 cigarettes each day for many years, was well until January 1969 when she developed right-sided pleuritic chest pain. There was no associated pyrexia. She had increased cough with sputum and had lost $4 \mathrm{lb}(1.8 \mathrm{~kg})$ in weight in two months before admission.

On examination her general condition was satisfactory. There was no associated clubbing of the fingers nor cyanosis. Examination of the chest revealed that air entry was diminished in the right upper chest both anteriorly and posteriorly and breath sounds were bronchial.

Chest radiographs showed a large mass at the apex of the right lung posteriorly and a smaller mass in the periphery of the right lower lobe with a suggestion of 


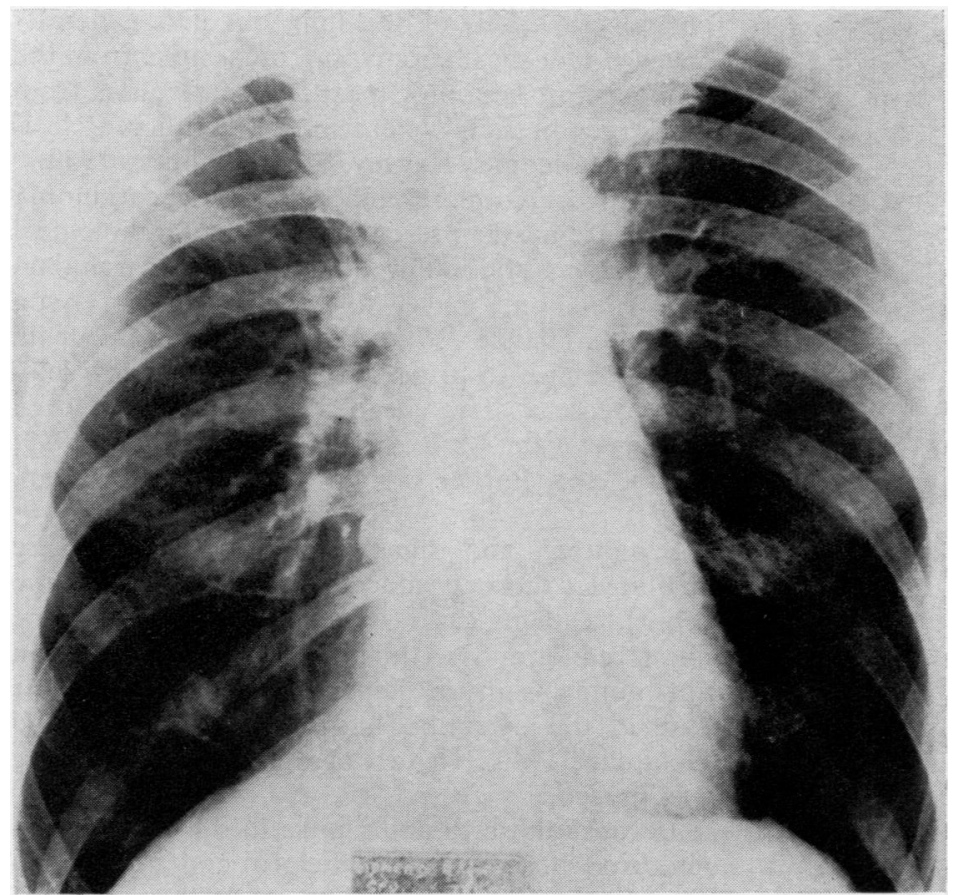

FIG. 3. Case 2. PA chest radiograph.

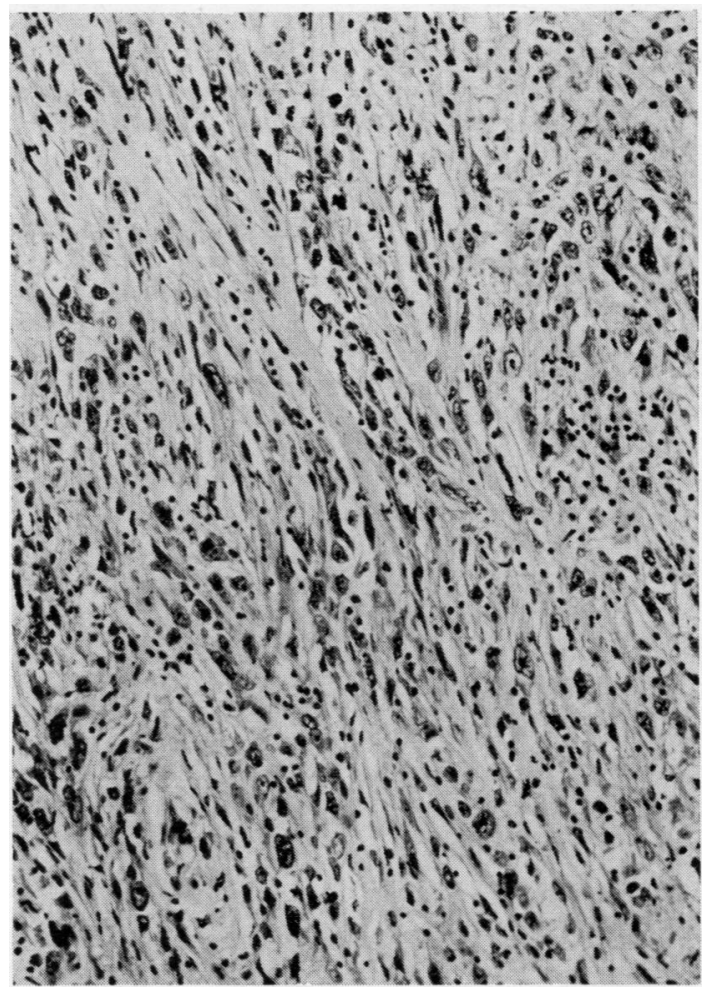

FIG. 4. Case 2. Large spindleshaped cells with large vesicular nuclei are seen $(\times 130)$. 


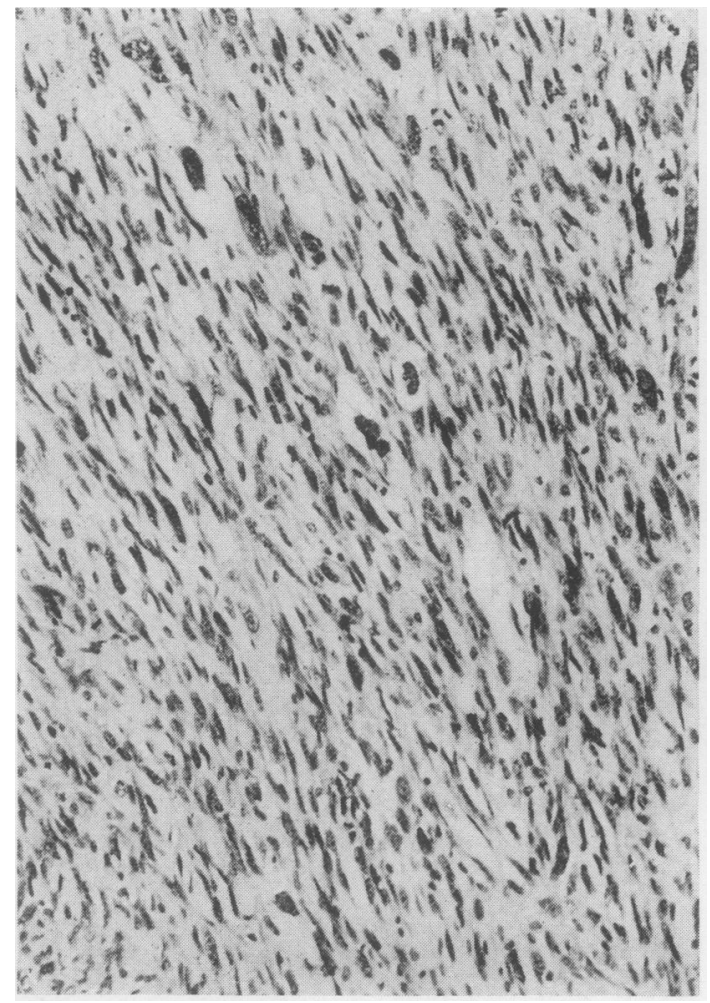

FIG. 5. Case 3. Most of the cells are plump with oval or round nuclei. Many giant cells are present (X130).

fluid at the right base. Examination of the sputum for neoplastic cells and bronchoscopy were normal.

On 19 February 1969 right thoracotomy was performed. A large mass was found occupying the entire upper lobe and fixed to the chest wall. In the diaphragmatic pleura and the lateral chest wall there were several metastases. The tumour was nonresectable.

Postoperatively the patient's condition deteriorated and she died on 28 March 1969.

HISTOLOGY (Fig. 5) A plaque of soft white growth $(4.5 \times 3.5 \times 1 \mathrm{~cm})$ was biopsied from the parietal pleura.

Microscopic examination shows an anaplastic growth consisting of interlacing bundles of spindle cells. Most of the cells are rather plump and some have oval or round nuclei. There are many giant cells and some mitosis. This is probably a poorly differentiated leiomyosarcoma.

\section{DISCUSSION}

Leiomyosarcoma is a malignant smooth muscle tumour. Smooth muscle is present in the bronchi and blood vessels of the lung but it is generally believed that most leiomyosarcomas arise from the bronchi. Further, they most frequently arise from the larger bronchi where most smooth muscle is present (Glennie, Harvey, and Jewsbury, 1959).

Leiomyosarcoma resembles bronchial carcinoma in its clinical presentation and radiological appearance, and differentiation from carcinoma is possible only on histological grounds (Dyson and Trentalance, 1964). The majority occur in the same age group as carcinoma but a few leiomyosarcomas have been described in children (Killingsworth, McReynold, and Harrison, 1953; Merrit and Parker, 1957; Watson and Anlyan, 1954).

Symptoms and signs of these sarcomas are similar to those produced by carcinoma of the bronchus. Our cases were detected on routine chest radiography. Clubbing of the fingers is an uncommon sign in leiomyosarcoma. Only one case in the literature had this sign (Brunn and Goldman, 1940). In two of our patients clubbing was present.

Because these tumours arise in the larger bronchi, bronchoscopy can be helpful and a preoperative diagnosis is possible in more than $50 \%$ of cases. In two of our three cases bronchoscopy was normal.

Sputum cytology is usually unhelpful even though atypical cells were noted in one case in the literature (Watson and Anlyan, 1954).

The diagnosis of primary leiomyosarcoma should be entertained only when there is no evidence of an occult primary elsewhere in the body, and in women the uterus should be carefully examined. In our female patients there was no evidence of tumour in the uterus on clinical examination. Case 2, who had haematuria, was found to have a well-differentiated transitionalcell papilloma of the bladder.

Metastatic spread is more likely in the poorly differentiated tumours and when present is mainly blood-borne (Mason and Azeem, 1965). Yacoubian, Connolly, and Wylie (1958) regard the absence of lymph node metastases as one of the characteristics of these tumours. In all our cases the regional lymph nodes were not involved on histological examination. None of the cases reported in the literature had metastases to the lymph nodes. This is in sharp contrast to the findings in bronchogenic carcinoma.

The prognosis is related to the degree of differentiation of the tumour and metastatic spread. Survival after excision of a leiomyosarcoma of the lung is better than that of primary lung cancer, 
and there seems to be a higher survival rate in patients with central than with peripheral sarcoma (Dyson and Trentalance, 1964). The three cases presented in this paper had very poorly differentiated centrally located sarcomas.

I wish to thank Mr. M. F. Sturridge, London Chest Hospital, for permission to present his cases, Dr. Hinson, consultant pathologist, Brompton Hospital, and the Photographic Department, Chester Beatty Research Institute.

\section{BIBLIOGRAPHY}

Agnos, J. W. and Starkey, G. W. B. (1958). Primary leiomyosarcoma and leiomyoma of the lung. New England Journal of Medicine, 258, 12.

Annamalai, A., Shreekumar, S., Vadivelu, P., and Shyamala, P. (1971). Complications during removal of pedunculated endobronchial leiomyosarcoma. Thorax, 26, 747.

Brunn, H. and Goldman, A. (1940). The differentiation of benign from malignant polypoid bronchial tumors. Surgery, Gynecology and Obstetrics, 71, 703.

Dyson, B. C. and Trentalance, A. E. (1964). Resection of primary pulmonary sarcoma. Journal of Thoracic and Cardiovascular Surgery, 47, 577.

Forkel, W. (1909). Ein Fall von Fibromyom der Lunge. Zeitschrift für Krebsforschung, 8, 390.

Gale, G. L. and Delarue, N. C. (1967). Leiomyosarcoma of the bronchus. Diseases of the Chest, 52 , 257.

Glennie, J. S., Harvey, P., and Jewsbury, P. (1959). Two cases of leiomyosarcoma of the lung. Thorax, 14, 327.

Hering, N., Templeton. J. Y. III, Haupt, G. J., and Theodos, P. A. (1962). Primary sarcoma of the lung. Diseases of the Chest, 42, 315.

Hewlett, T. H. and McCarty, J. E. (1958). Pulmonary leiomyosarcoma. Archives of Surgery, 76, 81.

Hicks, H. G. (1957). Bronchogenic leiomyosarcoma. Diseases of the Chest, 32, 338.

Holinger, P. H., Slaughter, D. P., and Novak, F. J. III. (1950). Unusual tumors obstructing the lower respiratory tract of infants and children. Transactions of the American Academy of Ophthalmology and Otolaryngology, 54, 223.

Hueck, O. and Matzander, U. (1958). Bericht über ein primäres Leiomyosarkom der Lunge. Thoraxchirurgie, 5, 494.
Johnson, E. K., Mangiardi, J. L., and Jacobs, J. B. (1952). Primary leiomyosarcoma of the lung treated by pneumonectomy. Surgery, 32, 1010.

Killingsworth, W. P., McReynold, G. S., and Harrison, A. W. (1953). Pulmonary leiomyosarcoma in a child. Journal of Paediatrics, 42, 466.

Mason, M. K. and Azeem, P. S. (1965). Primary leiomyosarcomata of the lung. Thorax, 20, 13.

Merrit, J. W. and Parker, K. R. (1957). Intrathoracic leiomyosarcoma. Canadian Medical Association Journal, 77, 1031.

Meszaros, G. and Simarszky, J. (1960). Primary leiomyosarcoma of the lung. Zentralblatt für die gesamte Tuberkuloseforschung, 115, 83.

Mishkin, J. A. (1951). Primary myosarcoma of the lung. New York State Journal of Medicine, 51, 1746.

Mylius, E. A. and Aakhus, T. (1961). Primary pulmonary leiomyosarcoma. Acta Pathologica et Microbiologica Scandinavica. Supplement, 148, p. 149.

Neumann, R. (1938). Leiomyosarcoma of the lung. Frankfurter Zeitschrift für Pathologie, 52, 576.

Ochsner, A. and Ochsner, S. (1958). Pneumonectomy for leiomyosarcoma. Journal of Thoracic Surgery, 35, 768.

Randall, W. S. and Blades, B. (1946). Primary bronchiogenic leiomyosarcoma. Archives of Pathology, 42, 543.

Rosenberg, D., Medlar, E., and Douglass, R. (1955). Concurrent primary leiomyosarcoma and carcinoma of the bronchus. Journal of Thoracic Surgery, 30, 44.

Shaw, R. R., Paulson, D. L., Kee, J. L., and Lovett, V. F. (1961). Primary pulmonary leiomyosarcomas. Journal of Thoracic Surgery, 41, 430.

Tocker, A. M., DeHaan, C., and Stofer, B. E. (1957). Primary pulmonary leiomyosarcoma. Diseases of the Chest, 31, 328.

Watson, W. L. and Anlyan, A. J. (1954). Primary leiomyosarcoma of the lung. Cancer, 7, 250.

Yacoubian, H., Connolly, J. E., and Wylie, R. H. (1958). Leiomyosarcoma of the lung. Annals of Surgery, 147, 116.

Requests for reprints to: T. Ramanathan, FRCS, Department of Surgery, University of Malaya, Kuala Lumpur, Malaysia. 